\title{
THE USE OF NON-VIRAL GENE VECTORS FOR BIOACTIVE POLY-(D,L-LACTIDE) IMPLANT SURFACES IN BONE TISSUE ENGINEERING
}

\author{
Ann K. Reckhenrich ${ }^{1,2 *}$, Christian Koch ${ }^{1}$, José T. Egaña ${ }^{2,3}$ and Christian Plank ${ }^{1}$ \\ ${ }^{1}$ Institute of Experimental Oncology, Technische Universität München, Munich, Germany \\ ${ }^{2}$ Department of Plastic and Hand Surgery, Technische Universität München, Munich, Germany \\ ${ }^{3}$ Center for Genome Regulation, Facultad de Ciencias, Universidad de Chile, Santiago, Chile
}

\begin{abstract}
The application of scaffolds in bone tissue engineering often comes along with side effects such as poor integrity, low regeneration rates of bone tissue with inadequate functionality, and, in case of non-degradable implants, the necessity of a second removal surgery after therapy. In this study, we coated a bioresorbable FDA-approved

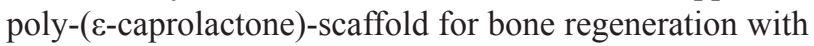
a poly-(D,L-lactide) layer containing copolymer-protected gene vectors to locally provide bone morphogenetic protein-2 (BMP-2). Results show that the presence of such gene vectors did not affect the distribution and attachment of seeded cells on gene-activated surfaces. BMP-2 was released into cell culture supernatants and furthermore detected in homogenised scaffolds. Increased amounts of osteoblastic markers, such as osteocalcin, osteopontin and the activity of alkaline phosphatase, in gene-activated scaffolds in vitro suggest a transdifferentiation of myoblastic $\mathrm{C} 2 \mathrm{C} 12$ cells into the osteoblastic phenotype. With this study we present a new technology to bioactivate implant surfaces with non-viral gene vectors. This tool allows the stimulation of tissue regeneration by a local release of therapeutic proteins in vivo.
\end{abstract}

Keywords: Non-viral gene therapy; controlled drug release; nanobiotechnology; bone regeneration; bioactive surface; implant integrity

*Address for correspondence:

Ann Katharin Reckhenrich, PhD

Technical University of Munich

Klinikum rechts der Isar

Department of Plastic and Hand Surgery

Ismaningerstr. 22

81675 Munich, Germany

Telephone Number: + 49/89/4140-7510

FAX Number: + 49/89/4140-7515

Email: ann.reckhenrich@1rz.tum.de

\section{Introduction}

Delayed healing, or non-union of bones, after traumatic events have tremendous impact on patients and health care systems (Donaldson et al., 2008; Garrison et al., 2010). Autologous transplantation of cortical and cancellous bone from iliac crest still remains the gold standard for the therapy of delayed or non-healing bone defects (Giannoudis et al., 2005; Lee and Shin, 2007). Although the simultaneous availability of osteoinductive factors, bone forming cells and osteoconductive matrices is beneficial, donor morbidity and limited availability remain drawbacks. Artificial bone substitutes present an alternative and should ideally provide osteogenicity, osteoinductivity and osteoconductivity, beside implant integrity (Bueno and Glowacki, 2009). The local regulation of bone regeneration underlies a distinct interaction of growth factors, hormones and cytokines with bone cells.

Bone morphogenetic proteins (BMPs) are crucial key substances for fracture healing (Barnes et al., 1999). BMPs are multifunctional proteins and are members of the transforming growth factor- $\beta$ (TGF- $\beta$ ) superfamily. In 1965, Urist observed their ability to initiate ectopic bone formation (Urist, 1965). The osteoinductive potential of BMPs in vivo has been reported in many animal studies and clinical trials (Bilic et al., 2006; Chen et al., 2004; Dimar et al., 2006; Gelse et al., 2003; Jones et al., 2006; Kirker-Head, 2000; Lee and Shin, 2007; Nakagawa et al., 2001; Okubo et al., 2000; Pelttari et al., 2006; Steinhardt et al., 2008). Only BMP-2 and BMP-7 are approved by the Food and Drug Administration (FDA) for clinical use to promote bone regeneration (Bessa et al., 2008a; Bessa et al., 2008b; Kanakaris et al., 2008). BMP-2 is indispensable for efficient fracture healing in bone (Tsuji et al., 2006). Different materials have been investigated in combination with recombinant osteoinductive biomolecules (Giannoudis et al., 2005). The half-life of recombinant human BMP-2 (rhBMP-2) is about 20-30 minutes (Valentin-Opran et al., 2002). Therefore, the application of these molecules to moderate a bone healing process of weeks or months (Marks and Popoff, 1988) has limited operational capacity. Recent methods to treat critical bone defects with implants are not satisfying and new innovative concepts deserve to be studied to regenerate bone with complete functionality.

Gene therapy allows local expression of specific growth factors. Viral gene vectors have been useful in tissue engineering (Margolis et al., 2000; Margolis et al., 2004; Mulder et al., 2009; Zhang and Godbey, 2006), but their use in humans is limited due to their difficult clinical 
translation, predominantly with respect to costs, efficacy and regulatory constraints. In contrast, non-viral vectors allow avoiding most safety concerns associated with viral vectors and are certainly less demanding concerning manufacturing, handling and costs. Their major limitation remains efficacy.

Here, we present a new technology to genetically activate implant surfaces to produce osteoinductive molecules with copolymer-protected gene vectors (COPROGs) encoding BMP-2 (Finsinger et al., 2000; Honig et al., 2010). Positively charged polyethylenimine (PEI)/DNA polyplexes are coated with an anionic polyethylene glycol copolymer, hence generating COPROGs, which prevents salt- and serum albumininduced aggregation and reduces, or abolishes, complement activation, known from unshielded PEI/DNA polyplexes as described before (Finsinger et al., 2000). A commercially available poly-( $\varepsilon$-caprolactone) (PCL) biomaterial was coated with a COPROG-containing poly-(D,L-lactide) (PDLLA) layer. The use of such COPROG-PDLLAcoatings for biomechanically stable, but degradable scaffolds, has several advantages. Both polymers, PCL and PDLLA, are aliphatic polyesters, which underlie mainly hydrolytic degradation in vivo and in vitro (Gunatillake and Adhikari, 2003; Middleton and Tipton, 2000; Wintermantel and Ha, 2009). The used PCL-scaffold (Osteomesh ${ }^{\circledR}$ ) is manufactured by fused deposition modelling (FDM) and possesses an interconnective pore network, biocompatibility and mechanical strength (Causa et al., 2006; Hutmacher et $a l ., 2001)$. This scaffold has been coated with fibrin glue containing rhBMP-2 to stimulate bone regeneration, but this approach only led to short release of BMP-2 in vitro (Rai et al., 2005). Another study presented positive effects of rhBMP-2-PDLLA-coating of titanium implants for bone healing and biomechanical strength of regenerated tissue (Schmidmaier et al., 2002). Moreover, a recently published article describes the feasibility of a COPROG/PDLLAcoating on non-degradable titanium implants in vitro (Kolk et al., 2011). The aim of this study was to evaluate whether the release of BMP-2 from BMP-2-COPROG-activated PDLLA-coated PCL-scaffolds can initiate differentiation of relevant cells and therefore enhance bone healing and integrity of such biodegradable implants.

\section{Materials and Methods}

\section{Plasmids}

The plasmid pMetLuccontrol, coding for Metridia luciferase as a secreted reporter protein, was purchased from Clontech Laboratories (Mountain View, CA, USA), expanded and purified by PlasmidFactory GmbH \& Co. (Bielefeld, Germany).

\section{Preparation of vector formulation}

Plasmid and branched PEI (25 kDa; Sigma-Aldrich, Deisenhofen, Germany) were mixed in water at an N/P ratio of 8 . After $15 \mathrm{~min}$ incubation, the resulting $\mathrm{PEI} /$ DNA complex was added to 2 charge equivalents of protective copolymer P6YE5C (synthesis as described before (Finsinger et al., 2000)) in water and incubated for $30 \mathrm{~min}$ at room temperature. All components were prepared in equal volumes before mixing as previously described (Finsinger et al., 2000), and COPROG solutions were lyophilised (Alpha 1-2 LD plus; Christ, Osterode, Germany). Lyophilised COPROGs were homogeneously suspended in a solution of $150 \mathrm{mg}$ PDLLA $/ \mathrm{mL}$ ethylacetate (EtOAc) with the use of a Teflon ${ }^{\circledR}$ pestle (Schütt Labortechnik, Göttingen, Germany).

\section{PDLLA-coating of poly-(E-caprolactone) scaffolds}

Osteomesh ${ }^{\circledR}$ (Osteopore, Singapore) was cut into diskshaped specimens with a $6 \mathrm{~mm}$ diameter punch (Acupunch; Xiomedics, Unterhaching, Germany). $50 \mu \mathrm{L}$ COPROG/ PDLLA/EtOAc-suspension containing $7.5 \mathrm{mg}$ PDLLA (Resomer ${ }^{\circledR}$ R203H; Boehringer Ingelheim, Ingelheim, Germany) and indicated amounts of COPROGs were distributed on scaffold surfaces. Control scaffolds were coated solely with a PDLLA/EtOAc-suspension containing $7.5 \mathrm{mg}$ PDLLA. After evaporation of EtOAc, polymer films remained and scaffolds were stored under vacuum overnight.

\section{Cell culture and transfection}

C2C12 mouse myoblasts (ATCC\# CRL-1772) were grown at $37{ }^{\circ} \mathrm{C}$ in an atmosphere of $5 \% \mathrm{CO}_{2}$ in Dulbecco's Modified Eagle Medium (DMEM; Biochrom AG, Berlin, Germany) supplemented with $10 \%$ foetal calf serum (FCS; PAN-Biotech, Aidenbach, Germany) and penicillin/ streptomycin (Biochrom AG, Berlin, Germany). $50 \mu \mathrm{L}$ medium containing 100,000 cells/scaffold was inoculated onto the dried scaffold. In order to ensure cell attachment to the scaffold an incubation step of $2 \mathrm{~h}$ was performed in culture conditions. Afterwards additional medium was added. After $24 \mathrm{~h}$, scaffolds were moved into 48 well plates containing fresh medium and culture medium was replaced every $2 \mathrm{~d}$.

\section{Scanning electron microscopy}

Scanning electron microscopy (SEM) was used to characterise scaffold structure. Samples were fixed with $3 \%$ glutaraldehyde (Sigma-Aldrich, Deisenhofen, Germany), dehydrated, dried, and sputtered with gold (BalTec SCD005, 30 mA, $240 \mathrm{~s}$ ). SEM was carried out using a JEOL-SEM JSM-5400 (Eching, Germany) in Hi-Vac mode by applying an acceleration voltage of $5 \mathrm{kV}$ and detecting secondary electrons for imaging.

\section{Metridia luciferase bioluminescence assay}

Cell culture supernatant was collected every $48 \mathrm{~h}$, being completely replaced and deep frozen $\left(-80{ }^{\circ} \mathrm{C}\right)$ until final measurements. For quantification, $50 \mu \mathrm{L}$ supernatant was mixed, in black 96-well plates (Corning, Tewksbury, MA, USA), with $20 \mu \mathrm{L} 0.05 \mathrm{mM}$ Coelenterazine (Synchem, Felsberg, Germany) and measured using a luminescence counter (Top Count; Canberra Packard, Dreieich, Germany).

\section{Quantification of metabolic activity - MTT assay}

$15 \mathrm{~d}$ after cell seeding, scaffolds were incubated for $1 \mathrm{~h}$ under culture conditions in phosphate-buffered saline (PBS) containing $500 \mu \mathrm{g} / \mathrm{mL}$ of 3-(4.5-dimethyl-2- 
A
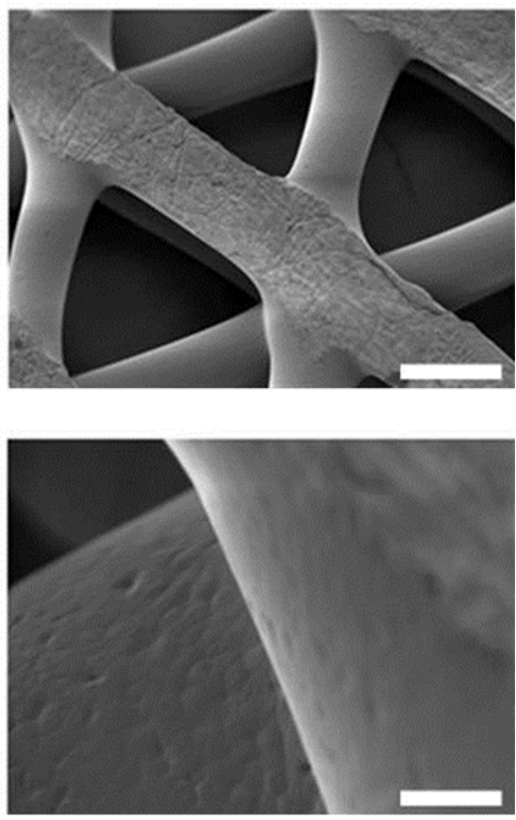

B
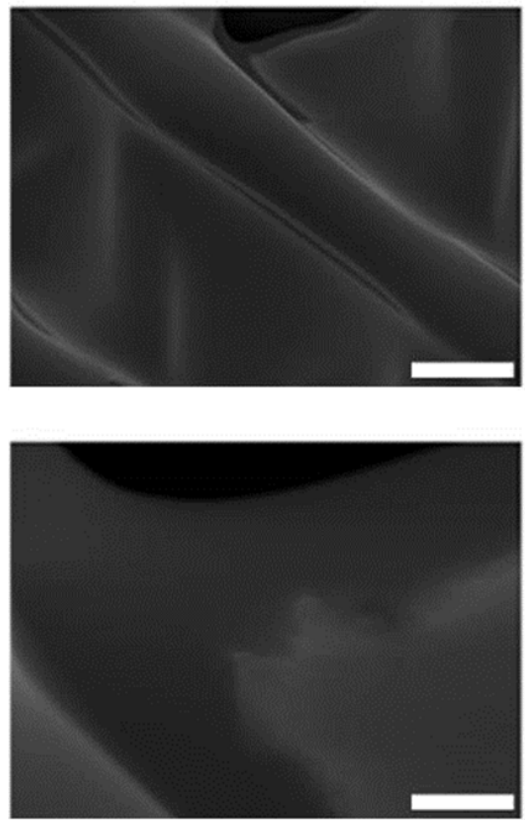

C
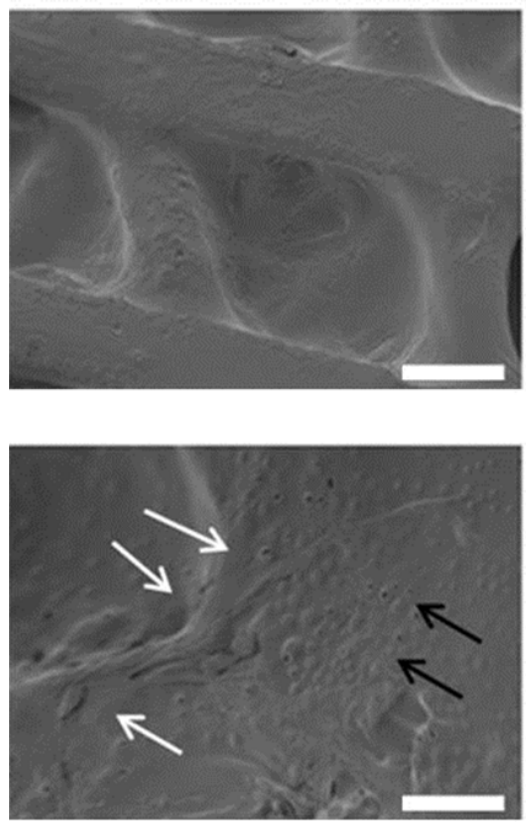

Fig. 1. Scanning electron microscopy pictures of native (A), PDLLA-coated PCL without cells (B), and $5 \mathrm{~d}$ after seeding of C2C12 cells onto PDLLA-coated PCL (C). Scale bar represents $500 \mu \mathrm{m}$ in upper panel and $50 \mu \mathrm{m}$ in lower panel.

thiazolyl)-2.5-diphenyl-2Htetrazolium bromide (MTT; Sigma-Aldrich, Deisenhofen, Germany). Next, MTT solution was removed and scaffolds were washed with PBS. Aferwards, scaffolds were incubated in $500 \mu \mathrm{L}$ dimethyl sulphoxide (DMSO; Sigma-Aldrich, Deisenhofen, Germany) until all formazan blue was extracted. Finally, absorbance at $560 \mathrm{~nm}$ was measured.

\section{Quantification of BMP-2}

BMP-2 concentrations in medium or protein extracts were measured by ELISA according to manufacturer's instructions (BMP-2 Quantikine ELISA Kit; R\&D Systems, Minneapolis, USA). The tissue samples were homogenised with a Mini-beadbeater ${ }^{\mathrm{TM}}$ (Biospec Products Inc.; Bartlesville, OK, USA; $1 \times 20 \mathrm{~s}$ pulses) in $2 \mathrm{~mL}$ screw-cap tubes (VWR Scientific Products, West Chester, PA, USA) containing $1 \mathrm{~g}$ zirconia beads ( $2.5 \mathrm{~mm}$; Biospec Products Inc., Bartlesville, OK, USA) and $0.5 \mathrm{~mL} 2 \mathrm{M}$ guanidine-HCl. Samples were kept on ice during the whole procedure. After centrifugation (7600 RPM for $5 \mathrm{~min}$ at $\left.4{ }^{\circ} \mathrm{C}\right), 100 \mu \mathrm{L}$ of the supernatant was analysed.

\section{Analysis of osteoblastic markers}

To determine the biological activity of manufactured BMP-2, the production of osteocalcin, osteopontin and the activity of alkaline phosphatase of $\mathrm{C} 2 \mathrm{C} 12$ cells was analysed. Osteocalcin was quantified in $100 \mu \mathrm{L}$ cell culture supernatants by ELISA according to manufacturer's instructions (Mouse Osteocalcin ELISA Kit BT-470; Biomedical Technologies Inc., Stoughton, MA, USA). Osteocalcin, osteopontin and the activity of alkaline phosphatase were analysed in $100 \mu \mathrm{L}$ homogenised scaffolds (Mouse Osteopontin ELISA Kit E0899Mu; USCN Lifescience Inc., Wuhan, China and p-Nitrophenyl
Phosphatase Liquid Systems; Sigma-Aldrich, Deisenhofen, Germany). All parameters are shown relative to the total amount of protein in samples, detected by Pierce ${ }^{\circledR}$ BCA Protein Assay Kits (Fisher Scientific, Schwerte, Germany).

\section{Statistical analysis}

All assays were repeated in at least 3 independent experiments. Statistical analysis with the comparison of only two groups was performed using Student's $t$-test. For the comparison of three or more groups, one way ANOVA was performed followed by post-hoc analyses. Data are expressed as mean \pm standard error of the mean.

\section{Results}

\section{Surface characterisation of PDLLA-coated PCL scaffolds}

The SEM analysis of surface conditions of PDLLAcoated and uncoated PCL scaffolds showed a very smooth surface after the coating procedure and pores were completely filled with PDLLA (Figs. 1A and 1B). $5 \mathrm{~d}$ after seeding C2C12 cells onto PDLLA-coated PCL, a regular distribution of adherent cells was observed. Cells showed usual morphology for this cell type (Fig. 1C; white arrows). Irregularities in PDLLA coating demonstrate beginning degradation of PDLLA after $5 \mathrm{~d}$ of cell culture (Fig. 1C; black arrows).

Optimisation of vector dose for efficient gene transfer Different amounts of COPROGs (with respect to DNA content) were immobilised on PCL scaffolds in PDLLA/ EtOAc suspension, and after evaporation of the organic solvent $\mathrm{C} 2 \mathrm{C} 12$ cells were seeded. Release kinetics of the secreted reporter protein Metridia luciferase (Fig. 2A) 
A

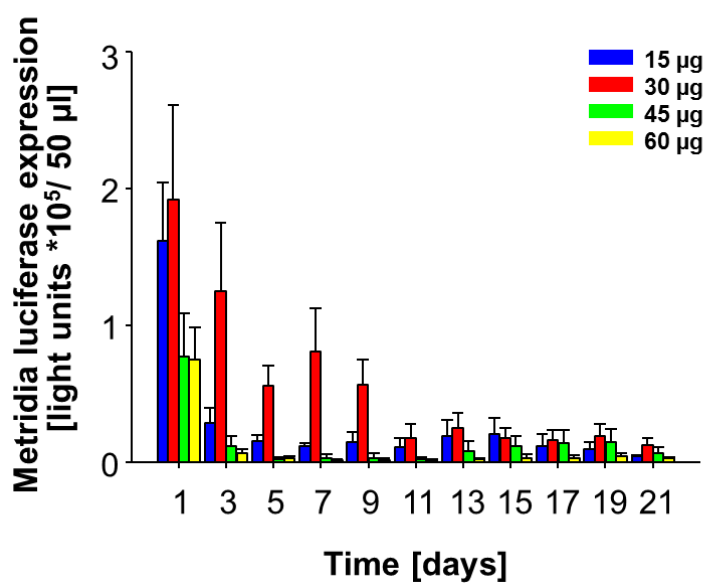

B

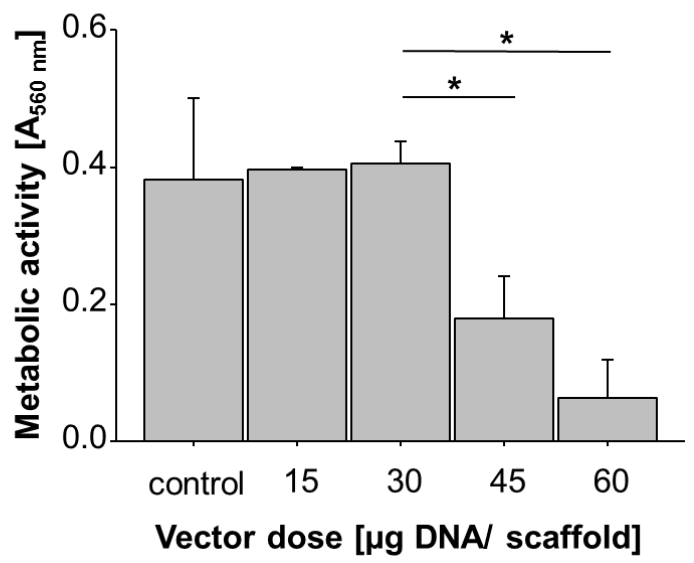

Fig. 2. Optimisation of gene vector dose. (A) Different amounts of COPROGs (with respect to DNA content: 15, 30, 45 and $60 \mu \mathrm{g}$ ) encoding reporter protein Metridia luciferase were suspended in $7.5 \mathrm{mg}$ PDLLA/50 $\mu \mathrm{L}$ EtOAc and protein release was observed in cell culture supernatants. Day 1 shows highest reporter protein concentration for 15 and $30 \mu \mathrm{g}$ pDNA. $30 \mu \mathrm{g}$ pDNA showed the highest amount of Metridia luciferase release for up to $9 \mathrm{~d}$. A further increase of vector dose was not followed by increasing protein release. (B) $15 \mathrm{~d}$ after cell seeding metabolic activity was determined with MTT assay. No differences in metabolic activity could be detected between control scaffolds and 15 and $30 \mu \mathrm{g}$ pDNA, but cells growing on 45 and $60 \mu \mathrm{g}$ pDNA showed significantly reduced metabolic activity $(p<0.05)$.

A

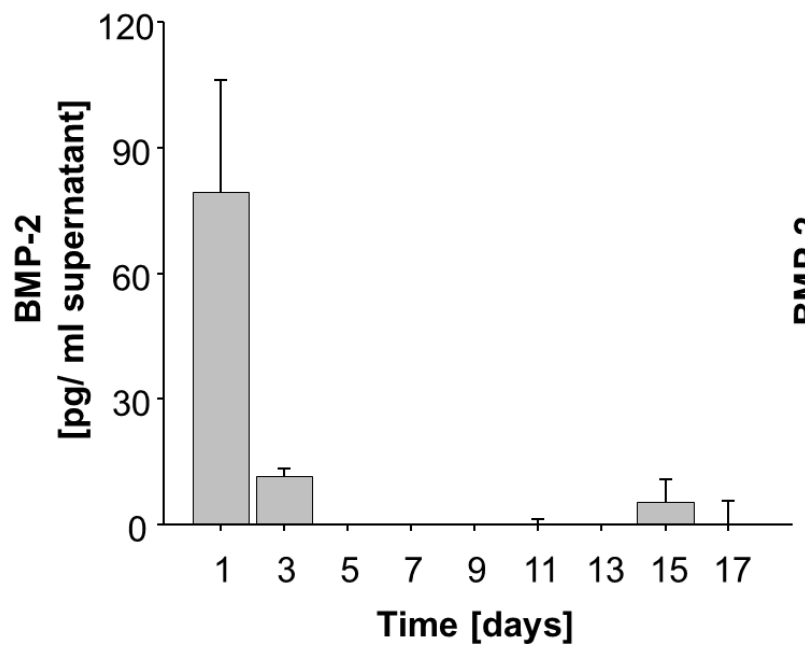

B

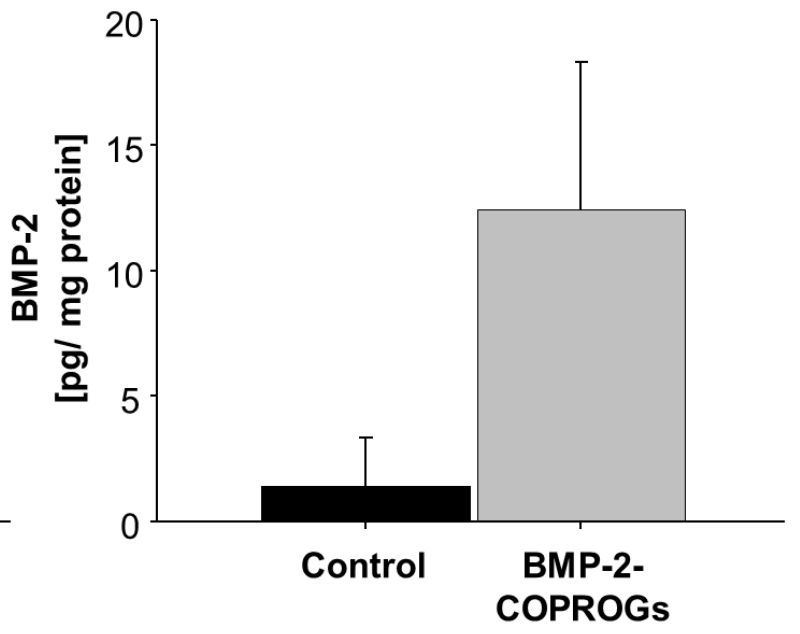

Fig. 3. BMP-2 expression. (A) $\mathrm{C} 2 \mathrm{C} 12$ cells were seeded on control or BMP-2-COPROG-activated scaffolds, and BMP-2 expression was analysed. BMP-2 release could be detected initially at day 1 and day 3 and also on day 15 in cell culture supernatants from BMP-2-COPROG-activated scaffolds. (B) After $17 \mathrm{~d}$, scaffolds were homogenised and showed 8 fold increased BMP-2-content in COPROG-activated scaffolds compared to control $(p=0.067)$.

and metabolic activity of seeded cells (Fig. 2B) were analysed relative to gene vector dose. Metridia luciferase was detected in cell culture supernatants of 15, 30, 45 and $60 \mu \mathrm{g}$ pDNA/scaffold. Furthermore, $30 \mu \mathrm{g}$ pDNA/ scaffold could facilitate a prolonged reporter protein release for at least $9 \mathrm{~d}$. A further increase of vector dose did not lead to increased protein expression (Fig. 2A). Metabolic activities of cells growing on control scaffolds and 15, $30 \mu \mathrm{g}$ pDNA/scaffold did not show differences, whereas it was significantly decreased for 45 and $60 \mu \mathrm{g}$ pDNA/ scaffold (Fig. 2B).

\section{Expression of growth factor BMP-2}

After verifying an optimal dose of $30 \mu \mathrm{g}$ pDNA (relative to COPROGs) $/ 7.5 \mathrm{mg}$ PDLLA $/ 50 \mu \mathrm{L}$ EtOAc condition for efficient gene transfer in vitro, BMP-2-COPROGPDLLA-coated PCL scaffolds were examined for their ability to release BMP-2 (Fig. 3). BMP-2-COPROGs were suspended in a solution of PDLLA in EtOAc, PCL scaffolds were coated, and the release of BMP-2 into culture supernatants was analysed (Fig. 3A). An initial BMP-2 release at day 1 and 3 was detected. BMP-2 in homogenised scaffolds was analysed after $17 \mathrm{~d}$ cell culture 
A

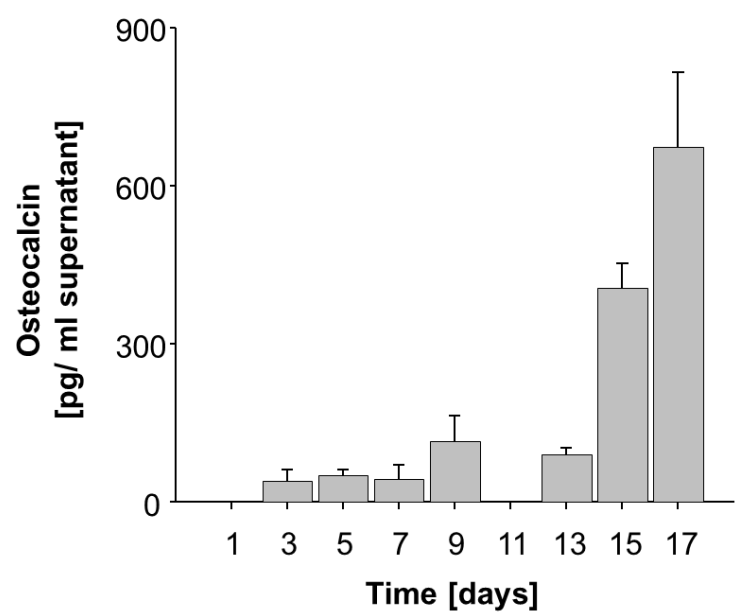

B

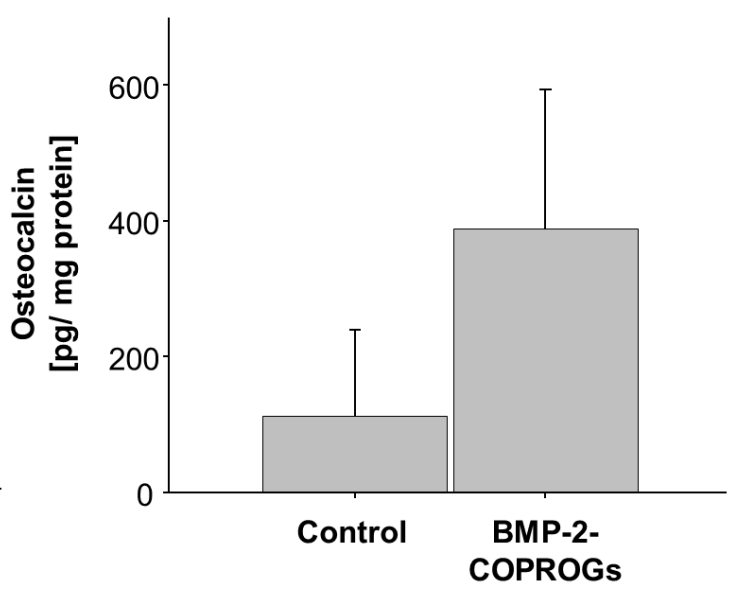

Fig. 4. Quantification of osteocalcin. (A) C2C12 cells were seeded on control or BMP-2-COPROG-activated scaffolds, and osteocalcin expression was analysed. Osteocalcin release showed exponential increasing values from day 3 on in cell culture supernatants from BMP-2-COPROG-activated scaffolds. (B) After $17 \mathrm{~d}$, quantification of osteocalcin in homogenised scaffolds showed an increase in COPROG-activated scaffolds compared to control.

A

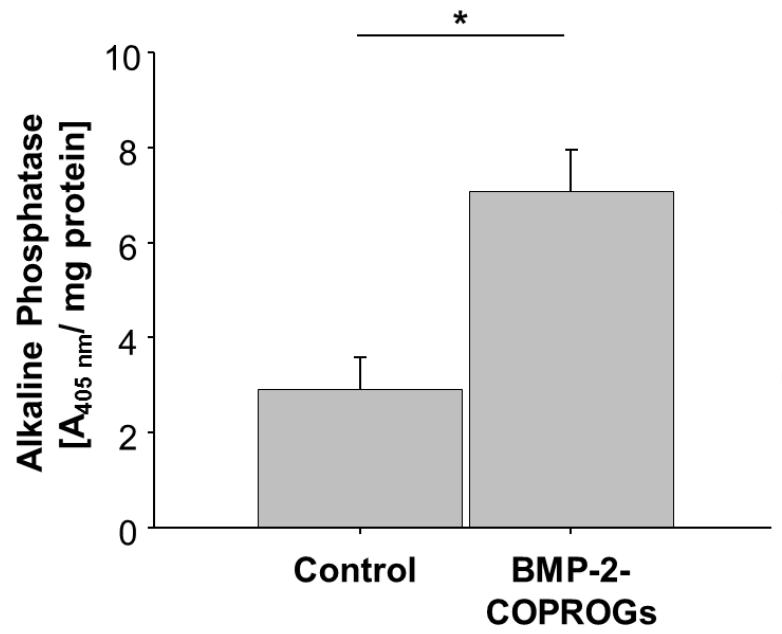

B

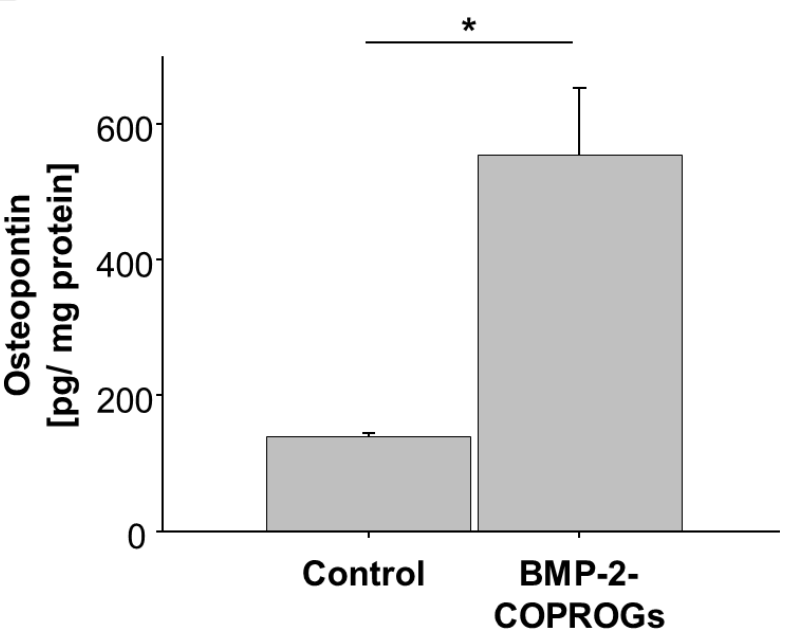

Fig. 5. Analysis of homogenised scaffolds. $17 \mathrm{~d}$ after seeding of $\mathrm{C} 2 \mathrm{C} 12$ cells on BMP-2-COPROG-PDLLAcoated PCL-scaffolds and control scaffolds the activity of alkaline phosphatase (A) and osteopontin-content (B) in homogenised scaffolds were analysed. Both parameters are significantly increased relative to controls $(p<0.05)$.

(Fig. 3B). After homogenisation of scaffolds in PBS (data not shown) no BMP-2 was detectable. After homogenising in $2 \mathrm{M}$ guanidine- $\mathrm{HCl}$ an average of $12 \mathrm{pg}$ BMP-2/mg total protein was detected in BMP-2-COPROG-activated scaffolds. This means an 8 fold increase to controls $(p=$ 0.067).

\section{Detection of transdifferentiation markers}

To determine, if the produced BMP-2 has a functional activity, osteocalcin production (Fig. 4) and osteopontin production and the activity of alkaline phosphatase of $\mathrm{C} 2 \mathrm{C} 12$ cells (Fig. 5) were determined. A release of osteocalcin by $\mathrm{C} 2 \mathrm{C} 12$ cells growing on gene-activated scaffold surfaces was observed from day 5 on, with exponentially increasing kinetics (Fig. 4A). The analysis of homogenised scaffolds after $17 \mathrm{~d}$ of cell culture shows a 3.5 fold increased amount of osteocalcin relative to controls
(Fig. 4B). The activity of alkaline phosphatase of C2C12 cells growing on gene-activated surfaces (Fig. 5A) and the amount of osteopontin (Fig. 5B) is significantly increased after $17 \mathrm{~d}$ cell culture $(p<0.05)$.

\section{Discussion}

The challenge of matrix-mediated therapy for non-healing or delayed healing of bone defects is allocation of adequate integrity at the defect site (Kanczler and Oreffo, 2008), along with delivering osteoconductive or -inductive properties, mechanical stability and load capacity. Different studies documented an improved bone healing after application of recombinant BMPs on PDLLA-coated titanium implants (Schmidmaier et al., 2002; Wildemann et $a l ., 2004)$. The duration of fracture healing, under natural 
conditions, lasts about 20 weeks (Garrison et al., 2010). Therefore, a prolonged supply of osteoinductive molecules is indispensable. Under consideration of systemic side effects, recombinant growth factors are not sufficient.

In this study the properties of a non-viral gene-activated surface coating of a mechanically stable, but biodegradable, material have been examined. The release of therapeutic molecules from COPROG-PDLLA-coatings of PCLscaffolds presents an increased osteoinductive potential of such bioactive surfaces. The very smooth coated PDLLAsurface of the PCL-implant (Fig.1B) did not affect the distribution, attachment or morphology of cells (Fig.1C, white arrows). After $5 \mathrm{~d}$ under cell culture conditions a beginning degradation of the PDLLA-layer was indicated (Fig. 1C, black arrows). To determine optimal gene transfer conditions comprising highest possible gene expression without cell toxicity, the relation of reporter gene expression and metabolic cell activity was determined. An increase of vector dose (with respect to DNA content) over $30 \mu \mathrm{g}$ pDNA/7.5 mg PDLLA/6 mm scaffold did not lead to further enhancement of protein expression (Fig. 2A) but to decreased metabolic activity of cells (Fig. 2B). Therefore this vector dose was considered to be optimal for further experiments.

BMP-2 plays a key role in the regeneration of bone and stimulates the proliferation and differentiation of progenitor cells to osteoblasts. Here, the production of BMP-2 after seeding C2C12 cells on BMP-2COPROG-PDLLA-coatings and the amount of BMP-2 in homogenised scaffolds was studied. The release kinetics of BMP-2 and reporter gene is similar (Fig. 2A and 3A). Initially, days 1 and 3 showed a distinct BMP-2 release to cell culture supernatants (Fig. 3A). After homogenisation of scaffolds in PBS, no BMP-2 was detectable (data not shown), but the homogenisation in $2 \mathrm{M}$ guanidine- $\mathrm{HCl}$ resulted in an 8 fold increase in BMP- 2 content relative to controls. Summarising this and the fact that after $5 \mathrm{~d}$ just minimal BMP-2 levels could be detected in cell culture supernatants (Fig. 3A) points to strong interaction of BMP-2 to the implant material. This observation suggests only local supply of BMP-2 at the implant side and can be advantageous in terms of avoiding systemic distribution and side effects of growth factors. BMP-2 release on day 1 and 3 was followed by an exponentially increasing release of osteocalcin (Fig. 3A and 4A). C2C12 cells showed a significant increased alkaline phosphatase activity on BMP-2-COPROG-activated scaffolds relative to controls after $17 \mathrm{~d}$ of cell culture (Fig. 5A). The quantification of osteocalcin and osteopontin in homogenised scaffolds showed a distinct increase relative to controls (Fig. 4B and $5 \mathrm{~B})$. This suggests a transdifferentiation of $\mathrm{C} 2 \mathrm{C} 12$ cells into the osteoblastic phenotype with BMP-2-COPROGPDLLA-coated PCL scaffolds.

This technology combines the osteoinductive effects of a BMP-2-COPROG-PDLLA coating with a mechanically stable, but biodegradable, PCL-scaffold. A translation to in vivo conditions is under further investigation. Here, we suggest that the stimulation of osteogenic differentiation of relevant cells in vivo can enhance the integrity of such implants in the defect area and improve mechanical loading and functionality of the regenerating tissue (Mavrogenis et al., 2009). This technology offers the opportunity to provide biodegradable or non-degradable, porous or non-porous scaffolds with a gene-activated COPROGPDLLA-coating, which according to the degradation rate of coating-polymers (here PDLLA) lead to a controlled release of therapeutic molecules after transfection of cells at the implant site and, therefore, can lead to an optimised treatment of bone defects.

\section{Conclusion}

This study presents a pioneering technology to prepare bioactive implant surfaces in a one-step procedure with a relatively easy clinical translation, as it can be performed under GMP standards, generating a stable product that is simple to implement in clinical settings. This innovative approach allows a local release of bioactive molecules and offers a cell-free and virus-free scaffold bioactivation strategy for degradable and non-degradable materials. Although in vitro results are promising, further studies should be performed to determine the optimal functionality of this approach in vivo.

\section{Acknowledgements}

This work was supported by the Deutsche Forschungsgemeinschaft (via the excellence cluster Nanosystems Initiative Munich) and by the German Federal Ministry of Education and Research (grant 0312019A). The authors would sincerely like to thank Stephanie Thomas from the Institute of Medical Engineering at Technical University Munich for assisting us with SEM and Dr. Lothar Schermelleh from LMU Biozentrum Munich for providing $\mathrm{C} 2 \mathrm{C} 12$ cells. The authors confirm that there are no known conflicts of interest associated with this publication and there has been no significant financial support for this work that could have influenced its outcome.

\section{References}

Barnes GL, Kostenuik PJ, Gerstenfeld LC, Einhorn TA (1999) Growth factor regulation of fracture repair. J Bone Miner Res 14: 1805-1815.

Bessa PC, Casal M, Reis RL (2008a) Bone morphogenetic proteins in tissue engineering: the road from the laboratory to the clinic, part I (basic concepts). J Tissue Eng Regen Med 2: 1-13.

Bessa PC, Casal M, Reis RL (2008b) Bone morphogenetic proteins in tissue engineering: the road from laboratory to clinic, part II (BMP delivery). J Tissue Eng Regen Med 2: 81-96.

Bilic R, Simic P, Jelic M, Stern-Padovan R, Dodig D, van Meerdervoort HP, Martinovic S, Ivankovic D, Pecina M, Vukicevic S (2006) Osteogenic protein-1 (BMP-7) accelerates healing of scaphoid non-union with proximal pole sclerosis. Int Orthop 30: 128-134. 
Bueno EM, Glowacki J (2009) Cell-free and cell-based approaches for bone regeneration. Nat Rev Rheumatol 5: 685-697.

Causa F, Netti PA, Ambrosio L, Ciapetti G, Baldini N, Pagani S, Martini D, Giunti A (2006) Poly-epsiloncaprolactone/hydroxyapatite composites for bone regeneration: in vitro characterization and human osteoblast response. J Biomed Mater Res A 76: 151-162.

Chen D, Zhao M, Mundy GR (2004) Bone morphogenetic proteins. Growth Factors 22: 233-241.

Dimar JR, Glassman SD, Burkus KJ, Carreon LY (2006) Clinical outcomes and fusion success at 2 years of single-level instrumented posterolateral fusions with recombinant human bone morphogenetic protein-2/ compression resistant matrix versus iliac crest bone graft. Spine 31: 2534-2539; discussion 2540.

Donaldson LJ, Reckless IP, Scholes S, Mindell JS, Shelton NJ (2008) The epidemiology of fractures in England. J Epidemiol Community Health 62: 174-180.

Finsinger D, Remy JS, Erbacher P, Koch C, Plank C (2000) Protective copolymers for nonviral gene vectors: synthesis, vector characterization and application in gene delivery. Gene Ther 7: 1183-1192.

Garrison KR, Shemilt I, Donell S, Ryder JJ, Mugford M, Harvey I, Song F, Alt V (2010) Bone morphogenetic protein (BMP) for fracture healing in adults. Cochrane Database Syst Rev 6: CD006950.

Gelse K, von der Mark K, Aigner T, Park J, Schneider H (2003) Articular cartilage repair by gene therapy using growth factor-producing mesenchymal cells. Arthritis Rheum 48: 430-441.

Giannoudis PV, Dinopoulos H, Tsiridis E (2005) Bone substitutes: an update. Injury 36 Suppl 3: S20-27.

Gunatillake PA, Adhikari R (2003) Biodegradable synthetic polymers for tissue engineering. Eur Cell Mater 5: 1-16; discussion 16.

Honig D, DeRouchey J, Jungmann R, Koch C, Plank C, Radler JO (2010) Biophysical characterization of copolymer-protected gene vectors. Biomacromolecules 11: 1802-1809.

Hutmacher DW, Schantz T, Zein I, Ng KW, Teoh SH, Tan KC (2001) Mechanical properties and cell cultural response of polycaprolactone scaffolds designed and fabricated via fused deposition modeling. J Biomed Mater Res 55: 203-216.

Jones AL, Bucholz RW, Bosse MJ, Mirza SK, Lyon TR, Webb LX, Pollak AN, Golden JD, Valentin-Opran A (2006) Recombinant human BMP-2 and allograft compared with autogenous bone graft for reconstruction of diaphyseal tibial fractures with cortical defects. A randomized, controlled trial. J Bone Joint Surg Am 88: 1431-1441.

Kanakaris NK, Calori GM, Verdonk R, Burssens P, De Biase P, Capanna R, Vangosa LB, Cherubino P, Baldo F, Ristiniemi J, Kontakis G, Giannoudis PV (2008) Application of BMP-7 to tibial non-unions: a 3-year multicenter experience. Injury 39 Suppl 2: S83-90.

Kanczler JM, Oreffo RO (2008) Osteogenesis and angiogenesis: the potential for engineering bone. Eur Cell Mater 15: 100-114.
Kirker-Head CA (2000) Potential applications and delivery strategies for bone morphogenetic proteins. Adv Drug Deliv Rev 43: 65-92.

Kolk A, Haczek C, Koch C, Vogt S, Kullmer M, Pautke C, Deppe H, Plank C (2011) A strategy to establish a geneactivated matrix on titanium using gene vectors protected in a polylactide coating. Biomaterials 32: 6850-6859.

Lee SH, Shin H (2007) Matrices and scaffolds for delivery of bioactive molecules in bone and cartilage tissue engineering. Adv Drug Deliv Rev 59: 339-359.

Margolis DJ, Crombleholme T, Herlyn M (2000) Clinical protocol: Phase I trial to evaluate the safety of H5.020CMV.PDGF-B for the treatment of a diabetic insensate foot ulcer. Wound Repair Regen 8: 480-493.

Margolis DJ, Cromblehome T, Herlyn M, Cross P, Weinberg L, Filip J, Propert K (2004) Clinical protocol. Phase I trial to evaluate the safety of H5.020CMV.PDGF-b and limb compression bandage for the treatment of venous leg ulcer: trial A. Hum Gene Ther 15: 1003-1019.

Marks SC, Jr., Popoff SN (1988) Bone cell biology: the regulation of development, structure, and function in the skeleton. Am J Anat 183: 1-44.

Mavrogenis AF, Dimitriou R, Parvizi J, Babis GC (2009) Biology of implant osseointegration. J Musculoskelet Neuronal Interact 9: 61-71.

Middleton JC, Tipton AJ (2000) Synthetic biodegradable polymers as orthopedic devices. Biomaterials 21: 23352346.

Mulder G, Tallis AJ, Marshall VT, Mozingo D, Phillips L, Pierce GF, Chandler LA, Sosnowski BK (2009) Treatment of nonhealing diabetic foot ulcers with a plateletderived growth factor gene-activated matrix (GAM501): results of a phase 1/2 trial. Wound Repair Regen 17: 772779 .

Nakagawa T, Sugiyama T, Kamei T, Murata T, Tagawa $\mathrm{T}$ (2001) An immuno-light- and electron-microscopic study of the expression of bone morphogenetic protein-2 during the process of ectopic bone formation in the rat. Arch Oral Biol 46: 403-411.

Okubo Y, Bessho K, Fujimura K, Konishi Y, Kusumoto K, Ogawa Y, Iizuka T (2000) Osteoinduction by recombinant human bone morphogenetic protein-2 at intramuscular, intermuscular, subcutaneous and intrafatty sites. Int J Oral Maxillofac Surg 29: 62-66.

Pelttari K, Winter A, Steck E, Goetzke K, Hennig T, Ochs BG, Aigner T, Richter W (2006) Premature induction of hypertrophy during in vitro chondrogenesis of human mesenchymal stem cells correlates with calcification and vascular invasion after ectopic transplantation in SCID mice. Arthritis Rheum 54: 3254-3266.

Rai B, Teoh SH, Hutmacher DW, Cao T, Ho KH (2005) Novel PCL-based honeycomb scaffolds as drug delivery systems for rhBMP-2. Biomaterials 26: 3739-3748.

Schmidmaier G, Wildemann B, Cromme F, Kandziora F, Haas NP, Raschke M (2002) Bone morphogenetic protein-2 coating of titanium implants increases biomechanical strength and accelerates bone remodeling in fracture treatment: a biomechanical and histological study in rats. Bone 30: 816-822. 
Steinhardt Y, Aslan H, Regev E, Zilberman Y, Kallai I, Gazit D, Gazit Z (2008) Maxillofacial-derived stem cells regenerate critical mandibular bone defect. Tissue Eng Part A 14: 1763-1773.

Tsuji K, Bandyopadhyay A, Harfe BD, Cox K, Kakar S, Gerstenfeld L, Einhorn T, Tabin CJ, Rosen V (2006) BMP2 activity, although dispensable for bone formation, is required for the initiation of fracture healing. Nat Genet 38: $1424-1429$.

Urist MR (1965) Bone: formation by autoinduction. Science 150: 893-899.

Valentin-Opran A, Wozney J, Csimma C, Lilly L, Riedel GE (2002) Clinical evaluation of recombinant human bone morphogenetic protein-2. Clin Orthop Relat Res 395: 110-120.

Wildemann B, Kandziora F, Krummrey G, Palasdies N, Haas NP, Raschke M, Schmidmaier G (2004) Local and controlled release of growth factors (combination of IGF-I and TGF-beta I, and BMP-2 alone) from a polylactide coating of titanium implants does not lead to ectopic bone formation in sheep muscle. J Control Release 95: 249-256.

Wintermantel E, Ha SW (2009) Medizintechnik: Life Science Engineering. Springer-Verlag GmbH, Berlin, pp 265-270.

Zhang X, Godbey WT (2006) Viral vectors for gene delivery in tissue engineering. Adv Drug Deliv Rev 58: 515-534.

\section{Discussion with Reviewers}

Reviewer II: What is the explanation of the "optimal" vector dose of $30 \mu \mathrm{g}$ pDNA/7.5 mg PDLLA per scaffold? Why does a higher vector dose lead to a reduced metabolic activity of the cells?

Authors: The reduced metabolic activity of cells observed in this study is most probably not directly related to the amount of pDNA, but to one of the other two components of this gene vector. The used gene vector (COPROG) is composed of three components: pDNA, polyethylenimine (PEI) and the PEG-Copolymer P6YE5C. Polyethylenimine is a polycationic molecule and can lead to aggregation with negatively charged cell components and therefore, depending on its dose, affect the metabolic activity of cells. As a consequence there is a therapeutic window for the use of gene vectors. Here the desired gene vector dose comprises high gene transfer efficiency and no reduction of metabolic cell activity. In our settings, results indicated a vector dose containing $30 \mu \mathrm{g}$ plasmid DNA (pDNA) and $7.5 \mathrm{mg}$ PDLLA/ scaffold to be the highest possible dose of gene vector without affecting the metabolic activity of cells. 